\title{
Prevalence of Plasmodium falciparum and $P$. vivax in an area of transmission located in Pará State, Brazil, determined by amplification of mtDNA using a real-time PCR assay
}

\author{
C.R.T. Souza, T.A.A. Carvalho, R.C.G. Amaral, L.S. Cunha, \\ M.G. Cunha and J.F. Guerreiro \\ Instituto de Ciências Biológicas, Universidade Federal do Pará, Belém, \\ PA, Brasil \\ Corresponding author: J.F. Guerreiro \\ E-mail: joaofg@ufpa.br \\ Genet. Mol. Res. 11 (3): 3409-3413 (2012) \\ Received October 27, 2011 \\ Accepted September 9, 2012 \\ Published September 25, 2012 \\ DOI http://dx.doi.org/10.4238/2012.September.25.9
}

\begin{abstract}
The need for a more sensitive and time-efficient assay for malaria has led to the development of molecular assays involving real-time PCR (qPCR), a procedure that has the potential to detect low levels of parasitemia, identify mixed infections, and allow for precise differentiation of species via melting curve analysis or TaqMan fluorescence-labeled probes. Since the first study published in 2001 at least 17 assays have been developed, most of them using SSUrRNA as the target gene. We used qPCR to detect Plasmodium falciparum and $P$. vivax by amplification of mtDNA; this technique was evaluated on whole-blood samples from people living in areas of malaria transmission in the Brazilian Amazon region located in the area of inclusion of highway BR-163 (Cuiabá-Santarém) in Pará State: São Luiz do Tapajós, a municipal district of Itaituba $(\mathrm{N}=74)$; Três Boeiras, a municipal district of Trairão $(\mathrm{N}=134)$, and São Raimundo, a municipal district of Aveiro $(\mathrm{N}=62)$. The results from the real-time PCR-based method were compared to conventional microscopy and to
\end{abstract}


an established mtDNA-PCR assay. The qPCR (mtDNA) method was 16-19 times more efficient than the conventional PCR (mtDNA) and microscopy for detecting plasmodial infections.

Key words: Malaria; Plasmodium falciparum; Plasmodium vivax; Mitochondrial DNA; Real-time PCR

\section{INTRODUCTION}

The development of more sensitive and effective diagnostic tests can contribute considerably to the reduction of malaria cases, because these methods can be used as much in the confirmation of clinical diagnoses as they can in the detection of asymptomatic carriers (Bronzan et al., 2008). Microscopic examination of Giemsa-stained thick and thin blood films has long been considered the gold standard for malaria diagnosis. It is well documented that microscopy has limitations, however: it is time-consuming, and misdiagnosis of the infecting species is common if the microscopist lacks experience or parasitemia is low. Several alternative techniques for laboratory diagnosis of malaria - for example, serological methods and new rapid diagnostic tests for antigen detection - have been developed, but polymerase chain reaction (PCR) is becoming the gold standard for malaria diagnosis in research and reference laboratory settings in malaria-endemic and malaria-nonendemic regions (Perandin et al., 2004; Bronzan et al., 2008). Presently, DNA-based methods are used to detect Plasmodium through amplification of a sequence of small subunit ribosomal RNA genes. Nested PCR is added to increase specificity and sensitivity, partly because the target gene is present only in a limited number of copies (Snounou et al., 1993; Kimura et al., 1997). PCR-based assays have various advantages over conventional methods - namely, specificity and sensitivity - but also have limitations that require multiple PCR assays to be performed on each sample and an analysis of the various PCR products. Moreover, these techniques do not quantify the parasitemia (Perandin et al., 2004). Thus, for routine screening in which a large number of samples must be examined, analysis using nested PCR is limited owing to its laborious and expensive methodology (Hänscheid and Grobusch, 2002).

Cunha et al. (2009) have standardized a simple and sensitive PCR method to detect Plasmodium falciparum and P. vivax through the amplification of a mitochondrial DNA (mtDNA) sequence, which has the advantage of being present in a high number of copies in the infected cells, making the successful amplification of target genes more likely in a single-round reaction. Nevertheless, the need for a more sensitive and time-efficient assay has led to the development of molecular assays using real-time PCR (qPCR), a procedure that can detect low levels of parasitemia, identify mixed infections, and allow for the precise differentiation of species via melting curve analysis or TaqMan fluorescence-labeled probes. Since the first report on this technique in 2001 (Hermsen et al., 2001), at least 17 assays have been developed, most of which use small subunit ribosomal RNA as the target (Review in Bourgeois et al., 2010).

In this study, a PCR method to detect $P$. falciparum and $P$. vivax through amplification of mtDNA was devised and evaluated using whole-blood samples from people living in areas of malaria transmission in Amazonian Brazil. The results from the qPCR method were compared to those obtained with conventional microscopy and conventional mtDNA-PCR assay. 


\section{SUBJECTS AND METHODS}

\section{Subjects}

The applicability of the mtDNA-PCR method was tested in a cross-sectional study of 270 individuals living in 3 regions of malaria transmission located in the area of inclusion of highway BR-163 (Cuiabá-Santarém) in Pará State: São Luiz do Tapajós, a municipal district of Itaituba $(\mathrm{N}=74)$; Três Boeiras, a municipal district of Trairão $(\mathrm{N}=134)$, and São Raimundo, a municipal district of Aveiro $(\mathrm{N}=62)$.

We drew $2 \mathrm{~mL}$ blood from each individual for thick blood smear preparation and for molecular diagnosis of malaria infection. All blood samples were collected after obtaining approval for this study from the Ethics Committee of João de Barros Barreto Hospital, Pará, Brazil.

\section{Light microscopy}

Microscopic parasitemia examinations were performed using a thick film method by 2 experienced malaria field microscopists from the Federal University of Pará. All the slides were stained using Giemsa ( $\mathrm{pH}$ 7.2), and the results were reported as parasites per microliter (Brasil, Ministério da Saúde, 2005).

\section{DNA extraction}

DNA was extracted from $300 \mathrm{~mL}$ ethylenediaminetetraacetic acid-treated blood using a NeoIsoColumn kit (One Lambda Inc., San Diego, CA, USA) according to manufacturer instructions. DNA was eluted in a $200-\mathrm{mL}$ elution buffer (provided with the kit).

\section{PCR-based diagnostic assay}

PCR was carried out according to Cunha et al. (2009) using primers designed to hybridize with the mitochondrial cytochrome c oxidase genes of $P$. falciparum and P. vivax.

\section{qPCR}

qPCR was carried out using the 2 primers described by Cunha et al. (2009). A $20-\mu \mathrm{L}$ reaction volume was used that consisted of $9 \mu \mathrm{L} 2 \mathrm{X}$ QuantiTect SYBR Green (Applied Biosystems, Life Technologies Corp., Carlsbad, CA, USA), $0.3 \mathrm{nmol}$ of each primer, $1 \mu \mathrm{L}$ DNA template, and 5.2 $\mu \mathrm{L}$ RNase free water. Amplification and detection were performed under the following conditions: $10 \mathrm{~min}$ at $95^{\circ} \mathrm{C}, 40$ cycles of $15 \mathrm{~s}$ at $95^{\circ} \mathrm{C}$, and $1 \mathrm{~min}$ at $60^{\circ} \mathrm{C}$. Each experiment included one reaction mixture with DNA from an infected blood sample as a positive control and one reaction mixture with DNA from healthy individuals with no history of malaria as a negative control.

\section{RESULTS}

Among the 270 blood samples from the communities of São Luiz do Tapajós, Três 
Boeiras, and São Raimundo investigated using microscopic examination, infection was detected in only 1 sample from Três Boeiras positive for $P$. vivax (1/134, 0.7\%). The PCR (mtDNA) technique found 1 of 74 DNA samples (1.3\%) from São Luiz do Tapajós positive for $P$. falciparum and 1 of 134 samples $(0.7 \%)$ from Três Boeiras positive for P. vivax. When qPCR (mtDNA) was used, 34 of 270 DNA samples (12.6\%) were identified as positives: 14 samples (19.0\%) from São Luiz do Tapajós were positive for P. vivax, and 1 (1.3\%) was positive for $P$. falciparum; in the Três Boeiras samples, $17(12.7 \%)$ were positive for $P$. vivax. Mixed infections ( $P$. falciparum plus $P$. vivax) were also found with qPCR (mtDNA) in 1 case $(1.3 \%)$ from São Luiz do Tapajós and $1(0.7 \%)$ from Três Boeiras (Table 1). In summary, Plasmodium infection was not detected in the samples from São Raimundo using any of the 3 diagnostic methods, whereas in samples from São Luiz and Três Boeiras, detection of Plasmodium infection with qPCR (mtDNA) was several fold higher (16-fold for São Luiz and 19-fold for Três Boeiras) than that using conventional PCR (mtDNA) and microscopy.

Table 1. Prevalence of Plasmodium infections diagnosed by light microscopy of blood smears, conventional
polymerase chain reaction (PCR-mtDNA) and real-time PCR (qPCR-mtDNA) methods.
\begin{tabular}{llccccc}
\hline Locality & Method & $\mathrm{N}$ & $\mathrm{Pv}$ & $\mathrm{Pf}$ & $\mathrm{Pv}+\mathrm{Pf}$ & Prevalence \\
\hline São Luiz do Tapajos & Microscopy & 74 & 0 & 0 & 0 & 0 \\
& PCR (mtDNA) & 74 & 0 & 1 & 0 & $1(1.35 \%)$ \\
Três Boeiras & qPCR (mtDNA) & 74 & 14 & 1 & 1 & $16(21.6 \%)$ \\
& Microscopy & 134 & 1 & 0 & 0 & $1(0.7 \%)$ \\
São Raimundo & PCR (mtDNA) & 134 & 1 & 0 & 0 & $1(0.7 \%)$ \\
& qPCR (mtDNA) & 134 & 17 & 0 & 1 & $18(13.4 \%)$ \\
& Microscopy & 62 & 0 & 0 & 0 & 0 \\
& PCR (mtDNA) & 62 & 0 & 0 & 0 & 0 \\
& qPCR (mtDNA) & 62 & 0 & 0 & 0 & 0 \\
\hline
\end{tabular}

\section{DISCUSSION}

The detection and treatment of patients with subpatent, asymptomatic parasitemia is critical for the control of malaria in endemic regions because these carriers be reservoirs of the parasite and likely sources of infection. Although light microscopy performed under optimal conditions can detect parasitemia as low as 5 parasites $/ \mu \mathrm{L}(0.0001 \%)$ on thick blood smears (Warrell, 2002), molecular assays, particularly those involving qPCR, are well documented to have various advantages over microscopic examination. Compared with the gold-standard nested-PCR assay, qPCR methods have shown high sensitivity (100\%) and specificity (100\%) for the simultaneous detection of Plasmodium species and have the additional advantage of yielding results in less than $3 \mathrm{~h}$ (Perandin et al., 2004; Mangold et al., 2005; Boonma et al., 2007). To bypass one of the main limitations of the standard PCR technique, which is the need for multiple PCR assays on each sample because the target gene is present in only a limited number of copies, Cunha et al. (2009) standardized a PCR method to detect $P$. falciparum and $P$. vivax through amplification of an mtDNA sequence, which is present in a large number of copies in infected cells. In this study we attempted to improve this technique using qPCR via melting curve analysis to detect mtDNA (cytochrome c oxidase genes) from P. falciparum and $P$. vivax. The results confirm previous observations about the superiority of classic PCR over microscopy and that qPCR is more sensitive than conventional PCR for the detection of Plasmodium infections, even though the mtDNA of the parasite is used for the diagnosis.

Although the qPCR method requires specific material and is more expensive than mi- 
croscopy and conventional PCR (Berry et al., 2005), it presents advantages of rapidity, lower contamination, and better standardization and can be used for routine testing, particularly for the study of populations in endemic areas in which patients may be asymptomatic (Mens et al., 2007; Boonma et al., 2007; Gama et al., 2007; Veron et al., 2009) and in patients who have negative results on routine methods but are strongly suspected of having malaria (Bourgeois et al., 2010). Thus, qPCR assay based on the detection of mitochondrial cytochrome c oxidase genes may be the method of choice for specific situations, including detection in low-parasitized individuals.

\section{ACKNOWLEDGMENTS}

Research supported by the National Council for Scientific and Technological Development and the Federal University of Pará, Brazil.

\section{REFERENCES}

Berry A, Fabre R, Benoit-Vical F, Cassaing S, et al. (2005). Contribution of PCR-based methods to diagnosis and management of imported malaria. Med. Trop. 65: 176-183.

Boonma P, Christensen PR, Suwanarusk R, Price RN, et al. (2007). Comparison of three molecular methods for the detection and speciation of Plasmodium vivax and Plasmodium falciparum. Malar. J. 6: 124.

Bourgeois N, Boutet A, Bousquet PJ, Basset D, et al. (2010). Comparison of three real-time PCR methods with blood smears and rapid diagnostic test in Plasmodium sp. infection. Clin. Microbiol. Infect. 16: 1305-1311.

Brasil, Ministério da Saúde (2005). Manual de Diagnóstico Laboratorial da Malária. Brasília.

Bronzan RN, McMorrow ML and Kachur SP (2008). Diagnosis of malaria: challenges for clinicians in endemic and nonendemic regions. Mol. Diagn. Ther. 12: 299-306.

Cunha MG, Medina TS, Oliveira SG, Marinho AN, et al. (2009). Development of a polymerase chain reaction (PCR) method based on amplification of mitochondrial DNA to detect Plasmodium falciparum and Plasmodium vivax. Acta Trop. 111: 35-38.

Gama BE, Silva-Pires FE, Lopes MN, Cardoso MA, et al. (2007). Real-time PCR versus conventional PCR for malaria parasite detection in low-grade parasitemia. Exp. Parasitol. 116: 427-432.

Hänscheid T and Grobusch MP (2002). How useful is PCR in the diagnosis of malaria? Trends Parasitol. 18: 395-398.

Hermsen CC, Telgt DS, Linders EH, van de Locht LA, et al. (2001). Detection of Plasmodium falciparum malaria parasites in vivo by real-time quantitative PCR. Mol. Biochem. Parasitol. 118: 247-251.

Kimura M, Kaneko O, Qing L, Mian Z, et al. (1997). Identification of the four species of human malaria parasites by nested PCR that targets variant sequences in the small subunit rRNA gene. Parasitol. Int. 46: 91-95.

Mangold KA, Manson RU, Koay ES, Stephens L, et al. (2005). Real-time PCR for detection and identification of Plasmodium spp. J. Clin. Microbiol. 43: 2435-2440.

Mens P, Spieker N, Omar S, Heijnen M, et al. (2007). Is molecular biology the best alternative for diagnosis of malaria to microscopy? A comparison between microscopy, antigen detection and molecular tests in rural Kenya and urban Tanzania. Trop. Med. Int. Health 12: 238-244.

Perandin F, Manca N, Calderaro A, Piccolo G, et al. (2004). Development of a real-time PCR assay for detection of Plasmodium falciparum, Plasmodium vivax, and Plasmodium ovale for routine clinical diagnosis. J. Clin. Microbiol. 42: 1214-1219.

Snounou G, Viriyakosol S, Jarra W, Thaithong S, et al. (1993). Identification of the four human malaria parasite species in field samples by the polymerase chain reaction and detection of a high prevalence of mixed infections. Mol. Biochem. Parasitol. 58: 283-292.

Veron V, Simon S and Carme B (2009). Multiplex real-time PCR detection of P. falciparum, P. vivax and P. malariae in human blood samples. Exp. Parasitol. 121: 346-351.

Warrel DA (2002). Clinical Features of Malaria. In: Essential Malariology (Warrel DA and Gilles HM, eds.). 4th edn. Arnold, London, 191-205. 